\title{
COMBATING CORRUPTION RELATES MONEY LAUNDERING ACTIVITIES IN INDONESIA: A HOPE AND REALITY
}

\author{
Sigit Handoyo \\ Faculty of Economics Universitas Islam Indonesia \\ E-mail: sigit@fe.uii.ac.id
}

\begin{abstract}
Corruption in Indonesia has become a culture and systemic so that it could not be eradicated in the short period of time. As corruption is closely related to money laundering activities, it is not impossible that combating corruption also means combating money laundering activities. PPATK (Pusat Pengkajian dan Analisis Transaksi Keuangan) as the Indonesia's FIU (Financial Intelligence Unit) has hard works to reveal those money laundering and corruptions activities. Beside its obstacles, PPATK also has challenges in the future. This article presents a study which discusses Indonesian cases in relations to money laundering and corruption, as well as the challenges that will be faced by PPATK as the Financial Intelligence Unit in combating money laundering activities.
\end{abstract}

Keywords:corruption, money laundering, PPATK, FIU

\section{BACKGROUND}

As the response to the list issued by the NCCT (non-cooperative countries and territories) regarding combating money laundering activities, PPATK (Pusat Pelaporan dan Analisis Transaksi Keuangan) or The Indonesia Financial Transaction Reports and Analyses Center (INTRAC), intended to serve as a Financial Intelligence Unit (FIU) in Indonesia, was established on April 17, 2003 by the enactment of Law number 15 Year 2002 concerning the crime of Money Laundering as amended by the Law No. 25 Year 2003. This policy was taken by government in concerning the reality that most of the money that was laundered in Indonesia came from corruption activities since the era of New Order. Therefore, Indonesia, as apart of country in the world, should support FATF (Financial Action Task Force) in combating money laundering activities and terrorism financing.

As corruption and money laundering are positively correlated (Bartlett, 2002),
PPATK has crucial jobs in overcoming the issues of money laundering in Indonesia, since the country is listed as one of the most corrupt nations in the world (World Bank, 2003). As the consequences, PPATK has to become familiar with both types of money laundering related corruption activities as well as understand what kinds of the efforts will be (have been) done by the offenders to launder their dirty money.

In money laundering, large amount of cash will be converted from currency into some other forms. It must be moved from a cash-based transaction system to businessbased transaction system (Madinger and Zalopany, 1999). Generally offenders choose bank to launder their money through the advance of technology, such as by transferring money via banks which can be done more rapidly and easily. Another typology to launder dirty money is that corruptors sometimes try to launder their money by choosing more traditional ways such as establishing businesses with other persons, 
like relatives, and appoint them as the owners, while other typology of money laundering are by doing bribery or collusions (APG, 2006). These cases are sometimes difficult to be revealed both by financial institutions and PPATK because of many factors. It means, PPATK has a big challenge in combating money laundering related corruption crimes.

This article attempts to describe and analyse the corruption which has relationship with money laundering activities in Indonesia and challenges faced by PPATK in combating those activities.

THE RELATIONSHIP BETWEEN CORRUPTION AND MONEY LAUNDERING

The definitions of corruption might have been widely interpreted. However, it can be said in general that a corruption involves activities which are against the law and enriches one or more parties. The Law of Indonesian Republic Indonesia article 2 law no 31, 1999 stipulates that an act of corruption is "committed by any person/corporation who against the law enriches himself or another person/corporation, which may cause a loss to the state's budget or the state's economics." In the other definitions, corruption is often stated as a 'subculture' in various developing nations (Klitgaard, 1998), and corruption is hand in hand with 'collusion' involving government officials and rich businessmen, coupled with 'nepotism' preferences being given to family and friends (Komar, 2006).

Corruption and money laundering is positively correlated and this will occur when a country has a poor control in money laundering activity, the volume of crimes such as corruption is relatively high and vice versa. The corruptors, thus, will have wide opportunities to convert their illicit proceeds into legal money. In his article entitled "The Negative Effects of Money Laundering on Economic Development", Bartlett (2002) stated that there is a positive relationship between the volume of money laundering and vulnerability of corruption which is occurred in developing countries.

Referring to the case in Indonesia, the efforts of combating corruptions have been conducted since 1998. However, only limited results have been gained due to many factors, such as politic and economic reasons (Hamilton, 2001). It is not surprising that both politic and economic reasons are said to be the main reasons why combating money laundering related corruption have been difficult tasks to carry out in Indonesia as one of developing countries. With regard to the economic factors, the low income in public service may result in bribery which is considered one of the crime activities that supports money laundering. One case which supports the crime is, for example, when corrupting public officials are tipped by someone who involves in money laundering or corruption in order to provide fake identification documents such as passports, driving licenses or birth certificates (APG, 2006). Cutting their activities means to stop their tracks in money laundering activities (ADB, 2002). It also means that combating corruption may reduce money laundering activities in Indonesia.

Corruption and money laundering are units that cannot be separated from each other. Each of them can be both the cause and the effect. United Nations Officer for Drug Control and Crime Prevention (2006) stated in the report that money laundering strengthens corruption and organized crimes. Furthermore, APG (2006) underlined that corruption generates enormous profits to be laundered and facilitates numerous money laundering in supporting criminal activities. Thus, it is clear that corruption strongly related to money laundering activities.

\section{CORRUPTION IN INDONESIA}

As one of the most corrupt countries, Indonesia has very difficult problems 
to cope with. This condition is due to the widespread of corruption becoming a culture that has been for a long time conducted in Indonesia. "Supported" by the poor governance in the New Order era, corruption has been done in any level of the Indonesian people. In her research, Hamilton (2001) reported that corruption in Indonesia potentially occurs in all branches of government, the bureaucracy, the armed forces, the courts and law making institutions and can range from small-scale transactions involving relatively low-level officials to the wholesale plunder of public resources by those at the very top of the political structure.

Furthermore, issues of democratization and decentralization have led to a reduction in the federal corruption level. However, decentralization can not answer Indonesia away from the most diseases of the developing countries. Even worse, decentralization creates many other corruptions. This decentralization is lack of clarity on division of responsibilities (World Bank, 2003). Several reports indicate that corruption now has been decentralized to a large extent due to policies of political and administrative decentralization. The power shift to the regions has not been followed up with regional and local transparency and accountability measures (ADB, 2006).

Corruption in Indonesia may vary. Almost all aspects or sectors are touched by corruption. In order to have a description of corruption in Indonesia specifically, it is important to overview what sectors are related to corruption.

\section{SECTORS OF CORRUPTION}

Corruption in Indonesia based on the report of World Bank (2003) and Business Anti-Corruption Portal (2007) involves 9 sectors which are:

1. Judicial System

2. Police
3. License, Infrastructure and Public Utilities

4. Land Administration

5. Tax Administration

6. Customs Administration

7. Public Procurement and Contracting

8. Environment, Natural Resources and Extractive Industry

9. Labour Market

\section{Ad. 1 Judicial System}

Judicial system plays an important role in combating any crime in every country. Law enforcement can guarantee that every single case can be solved fairly and appropriately. In contrast, once judicial system is involved in the crime itself, any kind of crime will raise enormously including corruption. Offenders of crime believed anything can be bought by money even more justice.

In the 2001 survey conducted by the Partnership for Governance reform in Indonesia, the Indonesian judiciary and public prosecutions service were ranked among the most corrupt and least efficient institutions in Indonesia. It means that law enforcement in Indonesia was in the crucial stage. This reality brings any sector such as household sector and business sector not to use court to resolve any disputes.

The type of corruption in judicial system sector in Indonesia is bribery. This kind of corruption has been much known. However, it is not easy to be proven since lack of evidence. For instance, this type corruption in Indonesia: as reported by World Bank (2003), in the case of the higher courts including the Supreme Court, there are believed to be long established relations between judges and lawyers. Judges in lower courts are alleged to be in the habit of giving "gift" to their superiors to ensure that they are promoted or not posted to undesirable places. Even worse, the transaction of the 
verdict can be delayed or the sentence possibly needs not to be implemented.

\section{Ad.2 Police}

Absence of duty, misuse of operational funds, extortion of money from members of the public, bribery in handling criminal cases, bribery and nepotism in appointment and promotions, protection of gambling and prostitution and acting as debt collectors is poor portray of the Indonesian policepersons (World Bank, 2003). The poor condition above can be seen as backgrounds or reasons why corruption occurred. In the report by World Bank (2003), corruption in the police sector is pushed by the poor condition of the wealthy of people. The budget allocated to the police department in 2001, $77 \%$ is for the salary and only $14 \%$ was allocated for operational expenditure. Lack of the budget for the police department pushed this department to collect another funds to fulfill the budget for petrol and maintenance of vehicle. As the result corruption and bribery is such the only way to choose the answer. Reform in this sector has been conducted by government in Law no 2/2002 of the Police Law by separating this department from military and directly responsible to the President. As a result, the police department has its own budget. However, corruption in this sector has become already a root of its culture that cannot easily be eradicated.

\section{Ad.3 License, Infrastructure and Public Utilities}

Corruption in license, infrastructure and public utilities sectors are often occurred in several Kabupatens (regencies) impose illegal taxes and charges on interregional traffic. Also illegal fees levied by the police, judiciary and community groups are especially significant in the transportation sector (World Bank, 2003). Funds are often diverted from maintenance to the construction phase, where complex procedures and many stakeholders facilitate corrupt practices. The result is expensive roads that deteriorate due to insufficient maintenance.

\section{Ad.4 Land Administration}

Land value estimations are often subjected to negotiation and bribery, and property values are systematically undervalued in order to limit taxation. Furthermore, property rights are subject to corruption and inconsistent state intervention, and court rulings are not always consistent even though has been formally regulated by law.

\section{Ad.5 Tax Administration}

This sector is often subjected to foreign taxpayers and occurred in a state. Foreign taxpayers are at times faced with demands for bribes in order to collect their tax restitution since this is a very slow process that can take up to one year. Discrimination also occurred on foreign firms. Local business can at times avoid taxation, whereas foreign companies are almost always taxed both legally and sometimes illegally by local authorities. According to the World Bank Rural Investment Assessment, firms report that they pay bribes amounting to nearly $40 \%$ of the taxes they pay and this bribe payment typically occurs in the licensing procedures.

\section{Ad.6 Customs Administration}

Common customs related corrupt practice in Indonesia includes illegal transport charges, arbitrary valuation procedures and irregularities in container parking and transit charge. Also, cross-border flow of goods is inhibited by high costs and widespread corruption in the customs services. According to Transparency International, the customs is one of the most corrupt services in Indonesia, and custom laws are not enforced in a uniform manner. According to a survey cited by Global Integrity, the unof- 
ficial disbursement burden to importers in Indonesia was 800 millions USD in 2004.

\section{Ad.7 Public Procurement and Contracting}

Even though recent regulations have improved transparency in public procurement, there is still lack of transparency at local levels. Several cases of irregularities in public procurement are prosecuted in 2005-2006 and most of them were related to collusion between bidders and official through "mark up pricing". Collusion rings also exist where bidders take turn winning contracts and share the profit. Public procurement seems to be one of the most corruption-ridden sectors in Indonesia.

\section{Ad.8 Environment, Natural Resources and Extractive Industry}

Corruption in these sectors is predominantly related to forestry resources. Illegal logging contributes one of the biggest corruptions in Indonesia which is 27.9 trillion rupiahs (\$US 3 billions) every year since 2001(Syumanda, 2007). The corruption in these sectors is fostered by decentralization in which state government has authority to control the exploitation of natural resources. Furthermore, the Consensus Forest Boundary-setting of 1983 gave the state jurisdiction over three-quarter of the nation's land area. As a consequence, it creates localized corruption. Illegal logging which occurs in the forest-rich provinces involves a range of actors including: corrupt forestry officials, military and police personnel, illegal timber brokers, licensed timber concession-holders operating beyond the terms of their HPH contracts, local people engaged in informal logging and shippers, exporters, and customs officials (Setiono and Barr, 2003).

\section{Ad.9 Labor Market}

In this sector, corruption is particularly related to the protection of the labor. It is very common there is no contract to the labor and as the result when the labor is in the dispute, their position is very weak. Because of this condition, labor is seemingly pushed to do bribery.

The explanation above shows the vulnerability and the potential of corruption in Indonesia which occur not only in the lower level of but also more crucially involved in the higher level of the government and private strata. Corruption which is committed by lower level is more caused by the condition of economy as general. Whilst corruption is involving the higher level is more due to the culture of bureaucracy that can not be eradicated easily and instantly. It needs a long period of time to pull out the root of the corruption which has been occurring in Indonesia for a long time.

\section{MONEY LAUNDERING IN INDONESIA}

The term of money laundering in Indonesia had not become current issue until Indonesia was listed as Non Compliance Countries and Territories (NCCT) in 2001. Indonesia just realized about how big impact of money laundering to Indonesian economy because most of money, laundered by money launderer, came from corruption. For instance, one of the biggest corruptions in Indonesia is from illegal logging (Setiono, Barr, 2003). It is started in 1983 when there was given access to a large extra-budgetary source of fund, called reforestation fund, corruption in illegal logging becomes bigger (World Bank, 2003). Corruption in illegal logging is approximately 3 billion USD in every year since 2001 (Syumanda, 2007). As the result, the process of money laundering was needed by corruptors to convert their illicit money into legal proceeds. It happened and will happen with the other corruption in other sectors, which have been 
discussed previously. Since Indonesia did not have regulation in money laundering until 2001, money laundering activities could escape and became one of the crimes that were abandoned and untouchable. Even though there was no data revealing how many total funds as the result of corruption, Indonesia still becomes one of the countries which has a vulnerability in both corruption and money laundering. Therefore, corruption and money laundering become one of the most priorities agenda of the new reformed government.

Basically, typology of money laundering in every country has similarities. The difference in the typology is due to the difference in the condition of the country itself, such as policies, social, economy, culture and politics. In Indonesia, typology of the money laundering, stated in the PPATK report (2006) can be categorized into:

1. Transferring money from government institution to the individual (key person);

2. Using a fake identity to open account;

3. Bribery (using money);

4. Bribery (using luxuries goods);

5. Using life insurance (for money laundering);

6. Conspirator in using account;

7. Tax restitution;

8. Budget reduction.

The Role of Banks and Financial Institutions in Money Laundering

The role of the banks and financial institutions in money laundering is very important. Money launderers use banks or financial institutions as intermediation to convert their dirty money into clean money. It is very easy to transfer money from one area to another area or country. It needs only 45 second through electronic transfer and to launder dirty money (FinCEN, 2004). Furthermore, technology in banking system, nowadays, still becomes vulnerable in money laundering process although there are 40
40 recommendations by FATF that should be obeyed. Banking system offers many facilities to the customer to transfer money only with the short time. ATM, Electronic Transfer, Credit Cards are the example the facilities provided by bank to ease customer to transfer money.

Banks and financial institutions in Indonesia play important roles in money laundering activities. Customer due diligence is still becoming the problem to reveal money laundering activities. Many banks in Indonesia are still worried to loose customer if they give information to PPATK in the process of an identification money laundering pattern. For example, the number of financial institutions in Indonesia in 2006 is 4,256. However, only 100 financial institutions have reported STR to PPATK in 2006 (PPATK, 2006). It indicates that most of financial institutions including banks, in Indonesia still do not seriously fight money laundering and corruption.

\section{Efforts Have Been Taken into Combating Corruption Relates Money Laundering}

As corruption is closely related to money laundering, it is crucial to fight corruption and money laundering continuously. Indonesian reformation was started in 1998 when the New Order stepped down from the government. From that time onwards, Indonesia has been seriously combating corruption whilst combating money laundering itself started in 2001 when Indonesia was listed as NCCT by FATF.

Efforts in combating corruption and money laundering have been conducted by Indonesia as a member of Asia-Pacific Partnership in Anti-Corruption countries. The efforts can be listed as follows (ADB/OECD, 2003):

a. Developing Effective and Transparent Systems for Public Service This effort includes: 
Adjust salaries and benefit to the level of economy.

Transparent hiring and promotion to help avoid abuses of patronage, nepotism, and favoritism. Fostering creation of an independent civil service, and help promote proper balance between political and career appointment are also taken.

$\square \quad$ The State Minister for Administration Reform circular regularly remains every government until to provide and maintain a public compliant mechanism and follow up complaints immediately

$\square \quad$ Rotate officers which have been 2 or 5 years in their position

$\square$ Prohibition and restrictions governing conflicts of interest in business

Every civil servant particularly in the level of Executives, Judicial and Legislative bodies, including directors of state-owned enterprises also members of KPKPN must declare his or her wealth to Committee for the Investigation into Civil Servants' Wealth or KPKPN

$\square \quad$ Introduce draft of State Finances Law to Parliament which has major principle on public expenditure management in Indonesia

$\square$ Launched bill of Financial Services Authority which is intended to give a mandate to a independent body for supervising banking, insurance, pension plan, securities, and other financial services

$\square \quad$ New audit supervisory and audit arrangement principles tied to be clearly defined to avoid duplication

$\square \quad$ Finalised the Accountability report of the government institution in order to be audited by Financial and Development Supervisory (BPKP)
Issued new government procurement regulations governing all procurement of goods and services

$\square \quad$ The State of Ministry launched circular no 37/2002 urge all of government institutions to intensify and speed up anti-corruption programs in each department.

b. Strengthening Anti-Bribery Actions and promoting Integrity in Business Operation, such as:

Ensuring the existence of legislation with dissuasive sanctions which effectively and actively combat the offence of bribery of public officials

$\square \quad$ Ensuring the existence and effective enforcement of anti-money laundering legislation that provide for substantial criminal penalties for the laundering of proceeds of corruption and crime consistence with law by enacting the money laundering law no $15 / 2005$ by the House of Representatives.

$\square \quad$ Training on conducting investigation for KPKPN, Attorney General's office and the National Police

$\square$ With the issuance of the law of commission for combating corruption (law 31/2002) by the end of year 2002, has been established the Commission for combating corruption whose function includes performing actions needed to investigate, prosecute, prevent and increase public participation

$\square \quad$ Signed extradition MoU with Government of Hong Kong for surrender of fugitive offender

$\square \quad$ Discussed "Witness and Victim Protection Bill", also has established National Committee of Corporate Governance 
c. Supporting Active Public Involvement, such as

Support of non governmental organizations that promote integrity and combat corruption also preparation and/or implementation of education programs aimed at creating an anti-corruption culture

$\square$ Instruction from president to government units to report the performance of the unit with regard to its strategic plan in combating corruption, collusion and nepotism

$\square$ Access to the information is currently widened with the press freedom related to corruption cases

$\square \quad$ Co-operative relationships with civil society group such as chamber of commerce, professional associations, NGOs, Labor unions, housing association, the media, and other organization. Government also give protection of whistleblower and give opportunities widely to NGOs to monitor of public sector programs and activities such as Indonesia Corruption Watch, Government Watch, and Masyarakat Transparency Indonesia.

\section{Legal Instruments in Combating Corrup- tion and Money Laundering in Indo- nesia}

One of the weaknesses in combating corruption and money laundering in Indonesia is to enforce the law. Thus, in order to ensure that corruption relates money laundering can be eradicated; regulations are required to support the actions. Since 1999, a number of laws have been enacted, including:

1. Law no. 28/1999 on Clean Environment by establishing the Commission to Audit the Wealth of State Officials (KPKPN),
2. Law no. 31/1999 and Law no. 20/2001 on Eradicating Criminals Acts of Corruption,

3. Law no.15/2002 on Eradicating Money Laundering

4. Law no. 30/2002 on the Establishment of the Commission for Eradication of Corruption (KPK).

5. The Presidential Decree on The Republic of Indonesia No. 81/2003 of Organizational and Working Procedure of PPATK

6. The Presidential Decree on The Republic of Indonesia No. 82/2003 of Procedure for Implementing Power of PPATK

7. The Presidential Decree on The Republic of Indonesia No. 1/2004 of National Coordinating committee for the Prevention and Eradication of Money laundering Crime

8. Bank of Indonesia Regulation No. 5/21/PBI/2003 of Application of Know Your Customer Principles

Also, important institutional developments have been with arrangement of state auxiliary bodies established with mandates and contribute to the fight against corruption. These bodies include Corruption eradication Commission (KPK); the National Ombudsman Commission; the National Law Commission; and the Commission for the Eradication of Money Laundering (PPATK).

\section{The Need of International Cooperation}

By joining actively in International organization relating anti-corruption and anti-money laundering, Indonesia will have many benefits, either solution and recommendation or the trend of money laundering, particularly related to corruption.

Indonesia, is currently involving in International organizations such as FATF, 
APG forum, Egmont Group, APEC and having cooperation's with 18 countries by signing MoU of sharing information for Financial Intelligence Unit (FIU) such as China, Mexico, Canada, Myanmar, Cayman Island, South of Africa and Japan. Until 2006, PATK has exchanged information with other FIU in other countries 140 times such as Australia, Belgium, Philippines, the US, Cook Island, China, Malaysia, Switzerland, Hong Kong, Singapore, Macau, the UK, British Virgin Island, Jersey, Mauritius and Peru.

\section{PPATK: Obstacles and Challenges in} Combating Money Laundering

With regard to combating money laundering related corruption, PPATK does not run its operation smoothly. There are some obstacles as well challenges that have to be faced by PPATK in the future. In the next discussion, it will be discussed the obstacles and challenges faced by PPATK.

\section{Add. 1. Obstacles}

Even though some efforts have been done to fight corruption and money laundering, Indonesia seems still in the difficulties. To fight those problems, having a good governance is a must for a country like Indonesia. Unfortunately, the quality of governance of Indonesia shows poor condition.

Based on the World Bank report (2007), the performance of a country can be measured by 6 governance dimensions: 1) Voice and Accountability; 2) Political Stability and lack of Violence; 3) Government Effectiveness; 4)Regulatory Quality; 5) Rule of Law; and 6) Control of Corruption. Indonesian government performance is still relatively low. All of the governance dimensions Indonesia has value lower than 50\% from 2003 to 2006 even though indicating gradual increase (Worldwide Governance Indicators, 2007).
Those governance dimensions above can not be separated from the effort in combating corruption and money laundering. This reality is the first obstacle for those who commit in fighting corruption and money laundering in Indonesia including PPATK. For illustration, due to the weakness on the rules and laws, until now there has been no revision of law in eradicating money laundering. It is known that FATF has $40+9$ recommendations related money laundering and terrorism financing but the previous law of Indonesia only match with 40 recommendations. This situation may limit the action of PPATK to combat money laundering. For example, in the recommendation no iii of 9 recommendations FATF about freezing and confiscating terrorist assets, PPATK can not take action further to push financial institution to freeze and confiscate the suspicious assets even though there is strong indication those illicit money for terrorism financing.

Other obstacle that has to be faced by PPATK is because there is no integrated information system technology in Indonesia supporting eradication on money laundering. Due to that situation, money launderers in Indonesia launder their illicit money in cash rather than by transferring money. Such as in property transaction, it is easier people to launder their money with this business in cash.

Furthermore, the shortage of the budget for PPATK becomes one of its obstacles. In order to work optimally, PPATK needs much more funds to build data mining technology to assist the pattern of money laundering. In 2006 PPATK open a tender in providing hardware and software in technology but no one vendor meet the qualification both technically and administratively. Without technology, it is impossible for PPATK to investigate STR and CTR in the short time. For illustration, in the US it needs 18 months to investigate 1 case but only 45 
seconds needed in transferring money (FinCEN, 2004). PPATK reported (2006) that CTRs and STRs reported by financial institution were 6,793 reports. Also lack of skills of the employees on Data Mining Technologies becomes a serious problem for PPATK to uncover the pattern of money laundering related corruption activities.

\section{Add.2. Challenges for PPATK}

As stated by PPATK in its report (2006), among the cases related money laundering corruption is the highest numbers with 178 cases from 433 and based on the World Bank (2003), Indonesia was listed as one of the most corrupt countries. It is not surprising fact that corruption becomes the first priority of Indonesia government.

Some efforts have been done so far. However, there is still unbalancing portion between the number of corruption both in cases and an amount of currency and the number of the cases have been revealed by Government. This is the first big challenge that PPATK has to reveal money laundering from corruption. Despite having only limited budget, PPATK should work effectively and efficiently.

The second challenge is how to create a system and method to prevent money laundering activities which is done by cash transaction For Example, property transaction in Indonesia, specially in small village is still done by cash transaction. It is very vulnerable for this kind of business becomes one of many choices for offenders to launder illicit money. Cash transaction is almost impossible to be traced and audited. However, this is one of big challenge to PPATK to formulate the method of tracking and auditing.

The third challenge of PPATK is that how PPATK should maintain cooperation with other institution such as the National Police, KPK, Attorney General and financial institution. By stipulating Decree of the President of Indonesia No. 1/2004 about national coordinating committee for the prevention and eradication of money laundering crime, PPATK has opportunities to fight money laundering activities widely. The committee which should build coordination with PPATK, stated on that Decree are Coordinating Minister for Political and Security Affairs, Coordinating Minister for Economy, Minister of Foreign Affairs, Minister of Justice and Human Rights, Minister of Finance, Head of the Police Force of the Republic of Indonesia, Attorney General of the Republic Indonesia, Head of the National Intelligence agency, and Governor of Bank Indonesia. However, PPATK still has difficulty to have coordination with another member of the committee, particularly in term of sharing information.

From the internal point of view, PPATK should keep maintaining good governance in its environment due to bribery in Indonesia has become a culture even in government departments. It can be run well if PPATK keep consistent in its duty in combating money laundering, particularly related corruption crime.

\section{CONCLUSION AND RECOMMENDA- TION}

\section{Conclusions}

Corruption in Indonesia is still becoming big issue that can remain for a long period of time. There are still a lot of corruption cases that have not been revealed. Those corruptions have been occurring in Indonesia for long time and has become culture and systemic. As there is a strong relationship between corruption and money laundering, it is not impossible in the future many corruption cases will be revealed if the pattern of money laundering can be carried out easily. PPATK as the Indonesian FIU, has been stipulating some efforts to eradicate money laundering activities by having cooperation both internally and internation- 
ally. However, there is still a lot of hard works that PPATK has to carryout, for instance, revealing the unsolved corruption cass. Furthermore, there is another cha 1lenge that should be faced by PPATK, which is immediately having an up dated data mining technology to assist to audit money laundering pattern.

\section{Recommendations}

Based on the conditions of PPATK, the writer recommends that:
1. There should be another regulation from the government which refers to $40+9$ recommendations FATF

2. PPATK should keep actively building cooperation with other institution, particularly in sharing information internally and internationally

3. PPATK should persuade the government to provide an up date data mining technology to ease the pattern of money laundering activities

4. PPATK should keep maintaining good governance in its environment

\section{BIBLIOGRAPHY}

ADB/OECD. (2003). Self Assessment Report Indonesia. http://www1.oecd.org/daf/asiacom/countries/index_IDS.htm

APG. (2006). Yearly Typologies Report 2005-2006 http://www.apgml.org/documents/docs/6/APG\%20Yearly\%20Typologies\%20Repor t\%2005-06 PUBLIC.pdf

Bartlett, B.L. ( 2002). The Negative Effects of Money Laundering on Economic Development. http://www.afp.gov.au/_data/assets/pdf_file/3597/money_laundering.pdf

Business Anti-Corruption Portal. (2007). Indonesia Data Table. http://www.business-anticorruption.com

FinCEN. (2004). Release 2004 SARS Totals. (accessed October 13, 2007, from Proquest: Criminal Justise Periodical Database).

Hamilton, N. 2001. Anti-Corruption Strategy in Indonesia, Bulletin of Indonesia Economic Studies. 37(1).pp. 65-82

Klitgaard, R. 2001. Controlling Corruption. Jakarta: Yayasan Obor Indonesia.

Komar, M. 2006. Challenging Corruption in Indonesia. www.iawj.org/what/Session2Komar.doc

Law of The Republic Indonesia No. 15, 2002

Law of The Republic Indonesia No. 25, 2003

Madinger, J. and Zalopany, S. 1999. Money Laundering: A Guide for Criminal Investigator. New York: CRC Press.

PPATK. 2006. Annual Report 2005-2006. (accessed September 1, 2007, from ProQuest: Academic Research Library database).

PPATK. 2006. Annual Report 2006. (accessed September 1, 2007, from ProQuest: Academic Research Library database). 
SIIERHI Vol. 10 No. 1, JANUARI 2008: 55 - 66

Setiono and Barr. 2003. Using Anti Money laundering Laws to Fight Forestry Crime in Indonesia. www.cifor.cgiar.org/publications/pdf_files

Syumanda. R. 2007. Deforestasi dan Illegal Logging.http://rullysyumanda.wordpress.com

The Presidential Decree on the Republic Indonesia No. 82, 2003

World Bank. 2003. Combating Corruption in Indonesia. http://siteresources.worldbank.org/INTINDONESIA/Resources/Publication/03Publication/Combating+Corruption+in+Indonesia-Oct15.pdf

World Bank.2007.

ADB. 2006. Governance and Institutional Capacity. http://209.225.62.100/Documents/CSPs/INO/2006

Worldwide Governance Indicator. 2007. Country Data Report for Indonesia, 1996-2006. http://siteresources.worldbank.org/INTINDONESIA/Resources/Publication/03Publication/Combating+Corruption+in+Indonesia-Oct15.pdf

United Nations Office on Drugs and Crime. 2006. Global Programme Against Money Laundering. www.unodc.org/unodc/en/money_laundering.html

, 2002. Basic Facts.

www.adb.org/documents/manuals/countering_money_laundering/chapter_01_pdf 